\title{
O ATLAS SUBMERSO: POR UMA HISTÓRIA DA TRADUÇÃO COMO HISTÓRIA DA NÃO-TRADUÇÃO
}

\author{
Roberto Mulinacci ${ }^{1}$ \\ -1Università di Bologna, Bologna, Italia
}

\begin{abstract}
Resumo: Indo aparentemente na contramão de uma tradição disciplinar que, aliás, só em tempos recentes parece ter chegado a atribuir a merecida relevância à história da tradução, o presente artigo visa agora a reler essa história através da categoria de "não-tradução", cujo balizamento conceitual tem demonstrado não só a óbvia inter-relação com o seu oposto (sendo, afinal, a tradução e a não-tradução as duas faces da mesma moeda), como também a legitimidade heurística de complementar uma abordagem histórica da tradução com essa espécie de perspectiva às avessas.
\end{abstract}

Palavras-Chave: Tradução; Não-Tradução; Historia da Tradução; Estudos da Tradução; Literatura Universal

\section{THE SUBMERSE ATLAS FOR A HISTORY OF TRANSLATION AS A HISTORY OF NON-TRANSLATION}

\begin{abstract}
Apparently going against a disciplinary tradition which only in recent times seems to have started to attribute the deserved relevance to the history of translation, this paper aims to reread this history through the category of "non-translation", whose conceptual framework has demonstrated not only the apparent interrelationship with its opposite (after all, translation and non-translation are two sides of the same coin), but also the heuristic legitimacy of complementing a historical approach to translation, with some sort of a topsy-turvy perspective.
\end{abstract}

Keywords: Translation; No-Translation; History of Translation; Translation Studies; World Literature 
L'omissione e la rinuncia non vanno equiparate alla negazione come risultato finale, prodotto espressivo, dictum, ma alla negazione come operazione logica, lavorio semantico, actio dicendi.

(Paolo Virno, Saggio sulla negazione, p. 185)

\section{Há uma pedra no meio do caminho...}

Entretanto o fenómeno da não-tradução vai sendo também objecto de interesse. João Ferreira Duarte já nos propôs uma tipologia de categorias da não-tradução. Em causa estão diversas razões por que não se traduziu certos textos/autores: situações de bilinguismo, de proximidade linguística, pela distância cultural, devido à censura institucionalizada e a embargo ideológico. O que, afinal, ressalta deste fenómeno é paradoxal: pode ser tão interessante estudar o que foi como o que não foi traduzido. Poderemos imaginar uma história da tradução como história da não-tradução? (Seruya - Contributos para uma história da tradução em Portugal - 17-18).

Uma história da tradução como história da não-tradução... Ao longo dos últimos anos, tenho vindo a me questionar bastante sobre o efetivo alcance da instigante pergunta acima mencionada de Teresa Seruya, que, tal qual o emplasto para Brás Cubas, acabou praticamente se constituindo para mim quase em ideia fixa pelo menos desde 2016, quando publiquei na revista $O$ Eixo $e$ a Roda, justamente sob aquelas insígnias um tanto enigmáticas da "não-tradução" ( $c f$. Mulinacci), um artigo dedicado às traduções italianas dos romances de Machado de Assis. Naquela ocasião, em particular, eu havia pretendido mostrar as implicações ocultas, inconscientes ou, simplesmente, imprevistas da não-tradução que às vezes se escondem por trás da imagem aparentemente luminosa, positiva e pujante da prática tradutória, no caso específico aquela inerente a esse grande escritor brasileiro, cuja obra, de fato, tem 
sido submetida na Itália, só a partir do começo do novo milênio, a um processo constante mas muito seletivo de retradução, levando assim à proliferação dos mesmos, poucos títulos mais importantes, em detrimento de todos os demais.

Contudo, se agora vou aproveitar aqui novamente essa ferramenta conceitual da "não-tradução", não é, claro, para repropor um análogo esquema crítico com relação a um outro case study qualquer, e sim, pelo contrário, para verificar a capacidade de refuncionalização daquele conceito em escala maior e em diferentes âmbitos culturais, testando, por assim dizer, a validade dele como uma espécie de "regra universal". Mas por que pensar em uma história da não-tradução e o que é que isto significa concretamente em termos historiográficos? De resto, como se pode fazer a história do que não existe e, mesmo supondo que seja possível, qual a vantagem de abordar a questão por esse ângulo?

Bem, antes de tentar responder a essas perguntas, preciso dar de novo um passo atrás, voltando àquele ensaio de Seruya que deu a largada a todo meu discurso e de que vou citar agora mais um trecho importante, contendo já, em embrião, algumas das respostas solicitadas. Ei-lo:

Ao contrário da história da economia, da literatura ou do cinema (entre tantos outros), uma história da tradução é um verdadeiro u-topos. Na verdade, nunca até à data se publicou uma obra com tal título. No entanto, grande parte da investigação praticada, nomeadamente em estudos de caso, contribui para uma história da tradução. [...] A nãoconcretização, até à data, de uma história da tradução devese à incomensurabilidade do projecto. Enunciem-se, entre outros, os seguintes problemas: A definição do objecto a historiografar está longe de ser óbvia. O facto da instabilidade histórica do conceito de tradução é uma redundância, já que é essa mesma instabilidade que justificaria acompanhar o seu percurso através dos tempos e das circunstâncias. Pergunta-se então: do é que falamos exactamente quando falamos de tradução? Dos textos? Da actividade? Da teoria? 
Dos métodos? Do ensino? Dos tradutores? É evidente que estamos em face do polissistema da tradução, ou até dos vários polissistemas da tradução." (Seruya - Contributos para uma história da tradução em Portugal - 16-17).

Começo pelo fim: a estudiosa portuguesa tem toda a razão. Quando falamos de tradução não sabemos bem do que é que estamos realmente falando, porque os objetos abarcados por esse rótulo - mesmo deixando de lado, nesse caso, as extensões catacréticas do termo - são vários e cada um deles é digno do maior interesse.

Tomemos, por exemplo, o objeto em tese mais fácil de historiografar, a saber, os textos traduzidos em uma dada cultura em um dado período, suponhamos no Brasil do ano de 2000 até hoje. Essa coleta de dados teria obviamente que levar em conta todas as traduções publicadas no país, incluindo, além das traduções de literatura, também as traduções técnicas, científicas, jurídicas, audiovisuais, etc., em suma, aquele conjunto enorme de textos que justamente Jean Delisle (22) chama de "pragmáticos" e que precisam integrar ineludivelmente o corpus de referência para que a análise não fique prejudicada de saída. Só que uma tal coleta, que às vezes, dependendo das épocas, pode virar, inclusive, um "trabalho arqueológico" (Seruya- Contributos para uma história da tradução em Portugal - 17), seria no fundo quase inútil se não acompanhássemos a lista das obras vertidas para o português brasileiro com as características delas do ponto de vista estritamente técnico, isto é, enquanto produtos tradutórios participando, afinal, também e sobretudo da história das poéticas da tradução e não apenas da história das suas políticas.

É claro que nós poderíamos, então, fazer um recorte do nosso objeto de estudo, decidindo justamente, por exemplo, restringir a pesquisa apenas à história da tradução literária e circunscrever a coleta de dados tão só a um período qualquer da história do país escolhido. Mas até um duplo recorte desse tipo, qualitativo e quantitativo, não poderia ficar imune às exigências de cientificidade previstas pelo método historiográfico e ligadas também a uma banal 
lógica numérica impondo um corpus textual maximamente inclusivo e não exclusivo, onde portanto deveriam caber todas as traduções de gênero literário publicadas naquela determinada parcela de tempo (e, desse ponto de vista, isto é, na ótica da definição do comportamento tradutório de um polissistema nacional, a tradução dos textos da literatura de massa vale exatamente como a dos clássicos).

Depois desse prévio levantamento de dados, porém, seria preciso passarmos para a fase sucessiva, ou seja, para a análise dos repertórios bibliográficos recenseados e para tal não haveria outra hipótese senão recorrermos aos estudos de caso disponíveis para cada tradução, conquanto tudo isso não equivalha ainda a fazer uma verdadeira história da tradução, porque um campo como este, independentemente do seu tamanho, não pode ser apreendido no seu conjunto simplesmente juntando pedaços de informações parciais e isoladas relativas a um cânone mais ou menos amplo de obras-primas selecionadas, mas precisaria, antes, ser estudado justamente como um sistema coletivo (sem considerar que, diferentemente do que acontece com as obras-primas literárias, as traduções das obras -primas não são automaticamente, em si, obras-primas do ponto de vista tradutológico e portanto pode ser que elas sejam muito menos relevantes para a história da tradução do que as traduções de obras menores e passadas despercebidas...).

Naturalmente, essas "histórias das traduções" - como eu chamo os estudos de caso em apreço - são com certeza necessárias e propedêuticas à "história da tradução" enquanto subdisciplina, a qual, porém, não pode ser identificada com elas: de resto, fazendo um paralelo mais do que legítimo, quem aceitaria uma história da literatura que se limitasse a listar, dentre os muitos autores pertencentes a seu repertório, apenas os mais famosos e consagrados, às vezes sem nem sequer acompanhar os dados bibliográficos essenciais das obras deles com comentários e análises suficientes para uma efetiva descrição desses textos?

Em outras palavras, fazer história da tradução, no caso específico da tradução literária, vai muito além do fazer a história das traduções de Shakespeare, de Goethe, de Cervantes, de Proust ou 
de Calvino, porque ela evidentemente deveria implicar um alargamento considerável da base de dados (não se pode construir uma séria história da tradução a partir de uma amostra que cobre apenas percentuais menores dos textos efetivamente publicados em um país) e, ainda mais, um maior esforço crítico no tocante à avaliação dos resultados concretos do trabalho tradutório, que, embora não se preste decerto a juízos decorrentes de um estéril reducionismo cientificista (por exemplo, com recurso a rigorosas grelhas de avaliação como aquelas propostas por Osimo 2016), nem merece, porém, ser deixado totalmente ao subjetivismo impressionístico dos leitores ou àquele profissional, mas não raro auto-absolutório, dos tradutores e sim, pelo contrário, tem que ser repensado em função de um horizonte bem mais amplo, inerente às condições de produção e recepção, quer do original quer da tradução.

Sem considerar que, na esteira das pertinentes observações de Anthony Pym, ao revisitar as propostas do grupo de Göttingen, continua infelizmente fazendo falta, nas abordagens remetentes à história da tradução, aquela componente explicativa que é o verdadeiro convidado de pedra de toda essa questão, uma vez que

neither [external nor internal history] can become properly historical until they project substantial responses to the far more vital questions - peculiarly overlooked in the Göttingen programmes - 'why this text?' ('why not another?'), 'why in this way?', 'why not in another?'). (Pym, 223)

Nesse sentido, ou a história da tradução, de qualquer tipo de tradução, aceita o desafio de se pensar como um conglomerado teórico, envolvendo todas as suas vertentes e mobilizando uma visão sistémica do seu objeto de pesquisa ou ela simplesmente não é, tertium non datur, se limitando a ser apenas um catálogo de casos exemplares, uma espécie, afinal, de ciência "idiográfica", concernente basicamente a fenômenos únicos. 
Aliás, para dar uma ideia do campo semântico abarcado pelo rótulo "história da tradução" basta ver, por exemplo, quais são as principais questões que, sob essa perspectiva, precisariam ser respondidas e que Lieven D'Hulst (399), na esteira da Ars Versificatoria de Mathieu de Vendôme, resume em uma série de perguntas em latim (Quis? Quid? Ubi? Quibus auxiliis? Cur? Quomodo? Quando? Cui bono?). Em suma, abordar a tradução em termos rigorosamente historiográficos parece uma empreitada absolutamente titânica, a ponto de Seruya (Contributos para uma história da tradução em Portugal -16) chegar a falar em "incomensurabilidade do objeto chamado 'história da tradução'", sendo, de fato, não só a pesquisa quantitativa como também a análise qualitativa das traduções de todo irredutíveis, na sua maioria, aos métodos tradicionalmente praticados no âmbito desse nosso território disciplinar e cujo enfoque primário consiste, via de regra, na comparação dos originais com as suas diversas versões interlinguísticas.

Não é por acaso que um dos maiores expoentes da tradutologia contemporânea, Edwin Gentzler, em um livro importante publicado em 2017 e dedicado à tradução como reescrita (Translation and rewriting in the age of post-translation studies), salientava a dimensão ainda bastante acanhada dessa estratégia descritiva, preocupada quase exclusivamente com a detecção das diferenças entre o texto fonte e o texto alvo e, pelo contrário, muito menos com as razões dessas diferenças ou inclusive com as repercussões daquelas versões aloglotas na cultura de chegada ${ }^{1}$. O livro de Gentzler aponta desde o título para esse além da tradução, isto é para os efeitos dela dentro do polissistema receptor - sendo afinal tudo isso condizente com a sua ideia de um novo, almejado cultural turn da área em pauta, chamado "Post-translation studies" -, mas, no fundo, ele está se debruçando de modo indireto sobre problemas que dizem

\footnotetext{
1 "However, in many ways, the field [of translation studies] stikes me as still restricted primarily focused on written texts and two-way comparisons, and neglecting pre- and post-translation conditions and effects. Scholars have documented how texts differ and have shown that translators often make changes, adapt and rewrite, but explaining why remains problematic." (Gentzler, 2).
} 
respeito profundamente à história da tradução, não só enquanto "discipline or subdiscipline that still has to find its way within Translation Studies" (D’Hulst, 403), como também enquanto assunto extremamente complexo a historiar e cuja efetiva exequibilidade está portanto ainda por ser completamente demonstrada.

E é, pois, nesse quadro que surge a minha proposta de ler a história da tradução sob outra perspectiva, aquela justamente oferecida pela categoria com certeza não menos problemática da "nãotradução", a qual, porém, longe de ser entendida como alternativa ao seu contrário, assume aqui uma função complementar, capaz de proporcionar um olhar diferente sobre os temas até agora debatidos. Ou seja, se a história da tradução, como vimos, é um objeto tão inapreensível na sua inteireza, uma vez que as suas inevitáveis lacunas acabam prejudicando a compreensão do conjunto, por que então não tentarmos apreender esse objeto exatamente pelos seus vazios, isto é, transformando o que parece uma simples ausência em uma possibilidade de interpretação do existente?

Em suma, se a história da tradução constitui, na opinião de Seruya, um "verdadeiro u-topos", cujo projeto científico é tido como incomensurável a respeito dos nossos esforços de realização, por que, em vez de nos limitarmos a preencher seus vazios, não tentamos também observá-la pelo ângulo do que é um $u$-topos absoluto, o não-lugar por excelência, a saber, justamente a não-tradução? Existem, aliás, muito boas razões para fazer isso, começando pela mais óbvia: a não-tradução é um epifenômeno da história da cultura bem mais comum do que a tradução e, para nos atermos apenas ao campo literário, o número de textos não traduzidos para outras línguas ultrapassa de longe o número dos que se encontram na situação contrária.

Não estou obviamente falando apenas em termos sociológicos, vale dizer, do impacto das traduções nos vários mercados editoriais nacionais, ou seja das porcentagens de textos traduzidos em relação ao total dos livros publicados em um dado país - o que seria já por si um parâmetro interessante, se, por exemplo, pensarmos que no maior mercado livreiro do mundo, o norte-americano, a incidência 
das traduções é absolutamente ínfima ( $c f$. Heilbron, Sapiro, 96) e confirmando portanto de maneira cabal o triunfo do princípio de não-tradução, mas estou me referindo, em escala mais geral, ao fato incontestável de que, apesar de toda a enorme relevância que a tradução tem hoje em dia na nossa aldeia global, ela continua representando um fenômeno minoritário no âmbito das dinâmicas culturais da República Mundial das Letras, já que, é claro, nem todas as obras literárias produzidas no mundo são automaticamente submetidas também ao processo tradutório, mas só uma pequena parcela do total.

Contudo, previno desde já a objeção: se algo não existe, talvez nem mereça ser levado em conta e, por conseguinte, torna-se completamente inútil nos debruçarmos sobre potenciais prototextos que nunca passaram para metatextos, a não ser que se queira transformar a análise científica em uma espécie de especulação filosófica. Mas não é bem assim, porque na tradução o que se vê e o que não se vê são, na realidade, as duas faces da mesma moeda, sendo, com efeito, as razões que levaram a traduzir um livro não menos importantes daquelas que determinaram a exclusão dele desse processo de conversão interlinguística, sem considerar que, muitas vezes, se trata inclusive de razões análogas, embora de signo contrário, para ambos os casos (por exemplo, o valor estético ou supostamente econômico de uma obra, que, de um lado, pode justificar a tradução e, do outro, desaconselhá-la).

Sempre que, obviamente, essas razões que presidem a uma escolha ou a outra não sejam meramente acidentais, isto é, não tenham a ver com circunstâncias fortuitas mais do que com definidos projetos editoriais, como, por exemplo, quando se traduz um texto porque se encontra em domínio público e portanto a editora não tem que pagar os direitos autorais ou, vice-versa, como quando não se faz uma tradução porque as despesas para a aquisição dos direitos seriam maiores do que as receitas previstas pela venda do livro (e pode inclusive acontecer - falo por experiência pessoal - que o tradutor seja pago pelo trabalho feito mas a tradução depois não saia por se considerar a publicação do livro economicamente desvantajosa). 
Nesse caso, porém, o caráter especulativo das duas justificativas, seja em prol da tradução seja contra, seria mais ou menos o mesmo tanto para o que existe, o texto traduzido, como para o que não chegou a existir e que chamamos justamente de não-tradução, segundo parece confirmado, dentre os muitos testemunhos possíveis, também por Mojca Medvedšek (95), a qual, ao apresentar um panorama das traduções de literatura portuguesa no seu país, a Eslovênia, diz não saber bem explicar por que a primeira obra vertida do português para o esloveno tenha sido, em 1925, $O$ romance de Amadis de Afonso Lopes Vieira - isto é, uma adaptação de uma novela de cavalaria quinhentista, o Amadis de Gaula -, limitando-se simplesmente a alegar "algum motivo pessoal" do tradutor Debeljak, que talvez possa ter conhecido pessoalmente o autor, conforme consta da autorização dele presente na primeira página da tradução.

Tudo isso só para dizer que se, com certeza, não é nada fácil explicar a ausência de uma tradução do catálogo dos vários polissistemas nacionais, não menos difícil pode se revelar, às vezes, também a tarefa de dar conta da presença de uma tradução, ainda que, sem dúvida, a tradução, diferentemente da não-tradução, seja sempre o resultado de uma escolha consciente, conquanto, como vimos, não necessariamente de ordem científica ou cultural e sim, não raro, ligada também a causas contingentes.

Só que aqui eu não pretendo minimamente me ocupar da nãotradução em geral, isto é das inúmeras causas, mais ou menos acidentais, que, ao longo dos séculos, impediram milhões de livros de circularem pelo mundo afora em línguas diferentes daquelas em que foram escritos, condenando-os assim, por simples desinteresse ou desconhecimento por parte das culturas alheias, a ficarem dentro das suas fronteiras nacionais. Muito pelo contrário, o que está agora em pauta é a não-tradução como evento, segundo definida em um brilhante artigo de Cees Koster (2010), ou seja, a ideia de que, exatamente tal como a tradução, também a não-tradução pode ter um impacto cultural relevante se conseguirmos demonstrar que "the absence of translation follows from intentional resistance that can ascribed to institutions or agents framed within a specific time 
span” (30). Perspectivada por esse prisma, então, a não-tradução deixa de ser apenas "the standard situation" (29) na história literária ou, no máximo, um mero acidente e passa, antes, a ser um elemento fundamental das dinâmicas de produção e consumo cultural, conforme mostra o próprio Koster ao analisar o interessantíssimo estudo de caso da recepção na Holanda do escritor estadunidense John dos Passos.

De fato, com base em resenhas e artigos de críticos literários neerlandeses, o estudioso chega a documentar como a não-tradução da obra de Dos Passos na Holanda entre 1925 e 1940, quer dizer, na época em que o escritor estava no auge da carreira, sendo considerado um dos autores principais da literatura mundial, não só adquire mais significado do que todas as suas traduções sucessivas - dentre as quais, por exemplo, a de Manhattan Transfer nos anos oitenta, quando o nome dele já tinha praticamente desaparecido da cena -, mas também pode ser concretamente atribuída à aversão da "patronagem" holandesa para com aquela estética modernista e vanguardista à qual Dos Passos de certo modo se filiava e, em particular, à aversão para com os aspectos formais e ideológicos dos seus romances, naquela altura ainda de inspiração esquerdista.

Desse ponto de vista, em vez de aventar hipóteses sobre uma mais ou menos plausível indiferença do meio cultural e editorial holandeses em relação ao autor norte-americano, Koster reconstrói documentalmente um contexto receptor desfavorável a esse tipo de literatura e onde, portanto, a opção consciente de não traduzir as obras de Dos Passos se torna, afinal, extremamente importante enquanto "a form of active resistance" (44), ou seja, como manifestação de uma vontade de resistência à mudança do clima artístico, sendo justamente o "cultural change" - Gentzler docet - uma consequência bastante frequente que a tradução arrasta consigo e que provavelmente podia ter arrastado também ali na Holanda dos anos Trinta.

Por falar nisso, uma situação mutatis mutandis parecida com a holandesa descrita por Koster se deu também no Portugal do final do século XIX, a propósito das traduções de Shakespeare, 
um autor muito popular no país, sobretudo desde 1877, quando da publicação do Hamlet, a primeira peça vertida, pelo rei Dom Luís, diretamente para o português do inglês e não do francês conforme acontecia anteriormente, virando logo essa tradução um autêntico marco da história da recepção lusitana do bardo de Stratford-upon -Avon. Não é portanto de se estranhar que, nos dez anos sucessivos, o número das traduções de Shakespeare em Portugal, incluindo traduções parciais, adaptações para o teatro e novas edições tenha começado a aumentar sensivelmente, segundo demonstram, dentre as demais, as traduções, sempre de autoria de Dom Luís, do Mercador de Veneza em 1879, do Ricardo III em 1880, do Otelo em 1885, que foi, por sinal, a primeira assinada pelo rei (as anteriores, com efeito, saíram anônimas) e assim por diante.

De repente, no entanto, a partir de 1890, aquela bibliografia shakespeariana em constante devir parece ter seu desenvolvimento interrompido até o início do novo século, quando começam a reaparecer outras retraduções e também traduções inéditas, como, por exemplo, a do Henrique VI. Mas por que esse hiato temporal na assim chamada "the age of Shakespeare" (Duarte, 101) em Portugal? Ou melhor, o que havia acontecido para fazer com que de um ano para outro Shakespeare deixasse de ser traduzido e adaptado para o público leitor - e, ainda mais, espectador - português?

Talvez seja possível responder convincentemente a essas perguntas repropondo a explicação avançada por João Ferreira Duarte - o pai (pelo menos em ordem cronológica) desse filão de estudo da não-tradução e, de fato, já citado por Seruya na abertura do presente trabalho -, o qual imputa a falta de traduções de Shakespeare na última década de Oitocentos à reação nacionalista suscitada em Portugal pelo Ultimatum inglês de 11 de janeiro de 1890, que desfazia o sonho imperial português representado pelo famoso Mapa Cor-de-Rosa, impondo à monarquia dos Braganças a imediata retirada das suas tropas dos territórios africanos disputados. Como se sabe, a frustração do país diante dessa cedência política levou a manifestações de rua contra a Inglaterra e a apelos ao boicote de tudo o que era britânico, inclusive em nível lexical, onde a anglofo- 
bia redundou em uma polêmica autarquia linguística, criando assim um clima cultural muito pouco propício - para usar eufemismos também à fruição de Shakespeare.

Desse ponto de vista, a não-tradução do bardo inglês no Portugal pós-ultimato se coloca ao lado da não-tradução de Dos Passos na Holanda dos anos Trinta, representando, uma e outra, dois emblemáticos exemplos daquela categoria do "embargo ideológico" que o próprio Ferreira Duarte tinha inserido como ponto mais alto da sua pioneira tipologia das políticas da não-tradução. Aliás, o "embargo ideológico" é porventura um dos motivos que mais se prestariam também para uma eventual projeção cartográfica da não-tradução como aquela implicitamente evocada pelo título deste ensaio, pois a sua dimensão estritamente ort-gebunden, isto é, ligada a um lugar específico e, ainda mais, às condições sociais, políticas, culturais de um dado país (e não, indiscriminadamente, de todo país) permitiria nos furtar às exigências de totalidade descritiva dos atlas, tradicionais e não ${ }^{2}$, de forma a podermos concentrar nossas análises nos casos exemplares, tornando, destarte, o mapeamento espacial epistemologicamente significativo.

Dito de outro modo: se o mapa mundial das traduções de um grande autor qualquer, por exemplo do mesmo Shakespeare, pode correr o risco às vezes, sobretudo hoje em dia, de virar culturalmente quase ilegível, de tão denso, homogêneo e uniforme que é, serão então justamente os terrains vagues da sua não-tradução, esses espaços residuais no catálogo da literatura mundial - residuais não só porque, de momento, vazios, mas também porque ainda disponíveis para serem preenchidos e por isso potencialmente cheios de significado -, que podem de vez em quando (nem sempre, claro, mas isso vale inclusive para a tradução, pois nem todas as traduções são sempre culturalmente significativas) proporcionar um insight valioso sobre os mecanismos da história da cultura, além dos da história da tradução.

${ }^{2}$ Ver, por exemplo, o excelente $A$ World Atlas of Translation (edited by Yves Gambier - Ubaldo Stecconi), Amsterdam-Philadelphia, John Benjamins, 2019.

Cad. Trad., Florianópolis, v. 41, no 1, p. 15-45, jan-abr, 2021. 
No entanto, o "embargo ideológico", embora seja talvez o mais relevante para iluminar a história daquela "pre-translation culture" de que fala Gentzler (4) e que, porém, às vezes se responsabiliza também pela não existência de uma tradução e não só pela produção de textos traduzidos, não é o único motivo citado por Ferreira Duarte (96-98) na sua casuística da não-tradução, a qual se compõe de mais seis categorias, em ordem crescente de importância cultural, indo, digamos, do texto para o contexto, a saber: omission, repetition, language closeness, bilingualism, cultural distance, institutionalised censorship e, na última posição, justamente o supramencionado ideological embargo.

As primeiras duas categorias de não-tradução são bastante intuitivas e, como sabemos, constituem parte integrante da praxe tradutória, sendo portanto, no meu entender, as menos interessantes do ponto de vista crítico e também as mais difíceis de avaliar no quadro do fenômeno em apreço. De resto, para que a omissão seja autenticamente relevante seria preciso, eu acho, que não se referisse apenas a uma palavra, mas dissesse respeito a porções mais ou menos amplas do texto-fonte ou, de qualquer maneira, a termos de alto valor simbólico, cuja ausência possa, em suma, prejudicar o devido entendimento textual da parte do leitor.

Por exemplo, podemos considerar sem dúvida uma manifestação típica da não-tradução aquelas omissões de passagens textuais que Marie-Hélène Torres (2008), em um instigante ensaio de alguns anos atrás, identificava nas traduções francesas de Alencar, em particular na edição do primeiro novecentos de Iracema, onde foram suprimidas as referências tidas como audaciosamente sensuais da relação entre Martim e a protagonista epônima do romance, e, mais em geral, nas versões e adaptações de Guarani, cujas notas de rodapé originais, disseminadas na obra pelo seu autor e funcionais ao melhor entendimento dela, foram submetidas a um apagamento indiscriminado. A estudiosa francesa fala, a respeito desse último caso, de não-tradução implícita - para a diferenciar da explícita (34), que, pelo contrário, teria a ver com formas de reelaboração mais consistentes como justamente a adaptação - e 
define a não-tradução como uma "atitude antropofágica colonial" que tende a se manifestar "na maioria dos casos sob a forma de censura" (34).

Digo já que concordo completamente com Torres, pelo menos no tocante a essas edições alencarianas publicadas na França, embora talvez nem sempre a não-tradução implícita resulte de uma espécie de censura moral ou ideológica em relação aos conteúdos das obras a serem traduzidas e possa às vezes tomar a forma de uma imprevisível e equivocada interpretação do ofício do tradutor, conforme demonstra cabalmente, por exemplo, a tradução inglesa de Dom Casmurro de autoria de Robert Scott Buccleuch, cuja inconcebível omissão de nada menos de nove dos 148 capítulos do romance machadiano parece ser provavelmente imputável - na opinião, ainda que prudente e duvidosa, de Daphne Patai (99) - à tentativa de Scott Buccleuch de preservar o ritmo narrativo do texto, subtraindo-o aos empecilhos das famosas digressões metanarrativas do Bruxo do Cosme Velho.

Contudo, deixando de lado esses episódios clamorosos de falta de profissionalismo - conquanto talvez ela seja um pouco mais justificada em Lebesgue, o tradutor de Iracema, levando em conta que a tradução francesa saiu em 1928, do que em Scott-Buccleuch, que verteu Dom Casmurro em 1994 -, a omissão no sentido indicado por Ferreira Duarte na esteira de Gideon Toury (82), isto é, enquanto "zero replacement", nem sempre é tão fácil de detetar e sobretudo de reconhecer como verdadeiro ato omissivo do tradutor. E não é fácil de reconhecer não só porque, em tese, cada palavra pode ser traduzida por outras, mesmo não de todo semântica ou pragmaticamente equivalentes e sem perturbar demais a compreensão do conjunto (por exemplo: Scott-Buccleuch que traduz "agregado" por "a friend of the family" peca por omissão ou por inadequação?), como também porque a omissão pode ser inclusive o resultado de um processo de negociação com o original e portanto passível de ser compensada pelo contexto tradutório, de forma a tornar a não-tradução de uma palavra ou de uma passagem em uma estratégia quase perfeitamente legítima do próprio ato de traduzir. 
Outro caso de estudo complicado de decifrar nessa perspectiva dicotômica é, por exemplo, a tradução italiana do romance de Ignácio Loyola de Brandão, Zero, que, como se sabe, devido à censura da ditadura militar na época vigente no Brasil, foi publicado originalmente na Itália, em 1974, e só no ano seguinte apareceu também em edição brasileira. Na verdade, a história editorial dessa obra-prima é um pouco mais complexa e interessante, porque, depois de ter sido rejeitada no Brasil por várias editoras, foi proposta pelo dramaturgo Jorge de Andrade, amigo pessoal do autor, a Luciana Stegagno Picchio e foi justamente ela quem sugeriu à editora Feltrinelli a publicação daquele texto datilografado de cerca de 400 páginas, entregando a tradução a um seu ex-aluno da Universidade de Pisa, Antonio Tabucchi, o futuro, famoso escritor de Afirma Pereira, que naquela altura já tinha traduzido para o italiano alguns poetas portugueses contemporâneos, dentre os quais, Alexandre O'Neill.

A tradução de Zero realizada por Tabucchi, como acontecerá depois também com as suas traduções mais famosas, in primis aquelas de Fernando Pessoa, é sem dúvida um trabalho bem feito, apesar, nesse caso, de várias omissões relativas principalmente a algumas frases com uma maior taxa de palavrões de conotação sexual ( $c f$. Felici), um traço bastante marcado da obra de Brandão e que na Itália de 1974 provavelmente era quase impossível de se reproduzir à risca, senão sob pena de condenar o livro a não ser publicado inclusive pelas nossas editoras, embora por razões basicamente de ordem moral e não ideológica como no Brasil.

Digamos então que a não-tradução de certas passagens julgadas obscenas demais para o sentimento comum do pudor do público italiano daquele tempo, juntamente com a tendência para uma eufemização do turpilóquio aplicada quase a todo o texto, podem caber dentro do quadro de mais ou menos legítimas estratégias tradutórias visando a privilegiar sobretudo o aspecto de denúncia política do romance e que, no caso contrário, podia ter sido realmente exposto ao risco concreto de esvaecer diante de uma eventual censura do livro. A autocensura de Tabucchi, afinal, teria sido o mal menor 
com vistas a impedir que a ameaça da verdadeira censura fizesse desistir a editora Feltrinelli de publicar o livro: esta é, pelo menos, a interpretação mais corrente em torno das vicissitudes editoriais de Zero na Itália.

Mas estamos realmente certos de que umas omissões de pouca monta, de resto quase completamente não prejudiciais à fruição do todo textual, possam configurar um caso de não-tradução propriamente dita? Ou seja: depois de Tabucchi ter eufemizado a escrita de Brandão o tempo todo, inclusive nas passagens mais audaciosas, será que ele precisava deveras omitir, por exemplo, uma frase como a seguinte: "Desculpem, nunca comi a mexicaninha. Só sozinho. Penso nela, e como. Do jeito que quero"? (cfr. Felici, 193) E, mesmo não justificando nada e ninguém, não será, pelo contrário, que essa omissão, tal como as demais, pode ser banalmente o produto de algum descuido do tradutor ou, quem sabe, da própria intervenção da editora, sugerindo cortar aqui e ali as excrescências narrativas mais chulas e menos funcionais?

Infelizmente, Tabucchi já morreu e nós não saberemos nunca a verdade, mas talvez seja possível aventar mais uma hipótese para dar conta de toda essa questão e é que Brandão tenha revisado e ligeiramente alterado seu texto quando da publicação no Brasil em 1975, de modo que as supostas lacunas da versão italiana são na realidade acréscimos sucessivos do original português (hipótese menos estranha do que se pense, visto que, por exemplo, a décima segunda edição de Zero, publicada em 2001 pela Global Editora, inclui também as seções do romance que o autor tinha deixado de fora nas edições anteriores; $c f r$. Bivona). Nesse sentido, se aceitarmos uma relação menos dogmática entre texto-fonte e texto-alvo, poderíamos quase chegar ao paradoxo de considerar a edição italiana de Zero o verdadeiro original do romance e, portanto, de fato, uma não-tradução, uma vez que - diferentemente do que acontece na indústria cultural contemporânea, onde os autores mais badalados (penso, dentre os muitos, em José Saramago) são publicados simultaneamente em diversos países, tendo porém como referência a edição original saída na pátria deles -, aqui falta, por sinal, a edi- 
tio princeps, ou melhor, a tradução coincide com a editio princeps, relegando o datiloscrito originário de Brandão ao papel de um antetexto ainda em vias de fixação definitiva (e daí derivaria também a atitude tradutória de Tabucchi, cujo esforço pela reelaboração textual parece se aproximar bastante da atuação de um editor ou talvez do próprio autor preocupado com o destino do livro, mais do que com o respeito pelo texto).

Trata-se de um paradoxo, ça va sans dire, mas nem tanto, levando em conta que em geral - salvo, repito, exceções extremas como as supramencionadas - não é tão fácil fazer uma equivalência estrita entre omissão textual e não-tradução e que, de qualquer maneira, às vezes o "zero replacement" de Toury, ainda que discutível, impróprio e errado do ponto de vista deontológico, funciona inclusive como uma forma de tradução e não como uma sua antítese.

Nessa ótica, o caso da repetição - ou seja, de palavras que se repetem sem variações no source text e no target text, sendo justamente a manutenção de alguns itens originais, em particular de tipo cultural-específico, um valor da tradução mais bermanianamente ética ao invés de que um símbolo de subalternidade de algumas culturas em relação a outras - representa mais uma confirmação de como quase toda a taxonomia das não-traduções em nível textual possa caber dentro, e não fora, do quadro das operações tradutórias, acabando, de fato, por contradizer o que parece hipostasiar (voltando, com efeito, à edição italiana de Zero, por exemplo, a não-tradução de certas passagens é a solução escolhida por Tabucchi propositalmente para que a tradução exista, e não o contrário, despotenciando, pois, o conceito de não-tradução enquanto ausência de tradução).

Por isso, acho que a única acepção de não-tradução que tem realmente cabimento e que vale a pena aqui investigar não é aquela filológica de uma tradução com maiores ou menores lacunas textuais e sim aquela cultural de uma lacuna da tradução enquanto texto impresso, a qual, conforme sugerido justamente por Ferreira Duarte, pode ter várias causas, das mais marginais tal como 
a proximidade linguística ${ }^{3}$ ou o bilinguismo ${ }^{4}$, às mais prementes, tal como a distância cultural, associada pelo estudioso português à não-tradução do Alcorão em Portugal até 1978 e que teria, por exemplo, uma espécie de equivalente, mas sob a categoria da censura institucionalizada, na não-tradução das obras de Marx e Engels no Portugal de Salazar.

Causas, essas, todas aparentemente tão lógicas - o que não significa, reparem bem, justificáveis -, que, dependendo do contexto, não podiam senão gerar reações na aparência igualmente lógicas e previsíveis, como pode ser, no fundo, a decisão de não traduzir o Alcorão em um país católico ou os clássicos marxistas em um país fascista. Em suma, tudo bastante previsto ou previsível. Mas...

\section{A não-tradução de "dictum" para "actio dicendi"(e retorno)}

... Mas será que a não-tradução pode ser pensada e perspectivada também através de uma relação dialética com a tradução e não simplesmente em contraposição a ela? Em outras palavras, se a tradução é afinal a ponta de um iceberg, será que a sua face imersa, a não-tradução, pode ser entendida como uma consequência dela e não apenas como uma alternativa a ela?

${ }^{3}$ Como, por exemplo, no caso do português e do espanhol, o que explicaria, no entender do poeta e crítico lusitano Jorge de Sena, mencionado por Duarte (97), a não-tradução de muitas obras espanholas em Portugal, apesar, contudo, de pesquisas bibliográficas recentes terem demonstrado que, na verdade, uma das línguas mais traduzidas durante o Estado Novo salazarista, em particular de 1940 a 1960, foi justamente o espanhol ( $c f$. mais uma vez Seruya - Translation in Portugal during the Estado Novo Regime - 126: "the dominant source culture for translation into Portuguese is Spain, at least after the 1940s"), que é hoje, revertendo a perspectiva, também "a língua com mais traduções do português" (cf. Queirós, https://www.publico.pt/2016/11/15/culturaipsilon/noticia/paulocoelho-e-saramago-sao-os-mais-traduzidos-1751172 , 30.11.2019).

${ }^{4}$ A tal propósito, por exemplo, José Lambert referia a falta de traduções do francês para o holandês na Bélgica, sendo ambas línguas oficiais do país e todos os belgas, portanto, idealmente bilingues ( $c f$. Duarte, 97). 
Vou tentar então propor agora um alargamento da tipologia da não-tradução incluindo o que eu considero novas modalidades plausíveis de leitura desse fenômeno, a começar por aquela situação historicamente tão comum, embora hoje em dia felizmente em ligeira diminuição, das traduções indiretas ou de segunda mão, vale dizer, traduções de traduções, as quais - por trás do aparente pragmatismo e neutralidade da operação, permitindo a uma cultura, quando não há condições para o fazer de modo direto, entrar em contato com outra por intermédio de uma terceira cultura -, acabam por ratificar, para além do costumeiro princípio de hierarquização das culturas, também uma evidente praxe de não-tradução da língua de partida (sendo normalmente as línguas-culturas não traduzidas aquelas dos países tidos como periféricos ou exôticos pelo estreito ângulo de visão dos países centrais do nosso sistema-mundo).

Nesse sentido, a não-tradução de línguas perífericas que se escamoteia nas dobras das traduções levadas a cabo em geral nas línguas híper-centrais, a partir das quais se fazem muitas das demais traduções que circulam pelo mundo afora (esta, pelo menos, era a regra até há umas décadas), se revela não só problemático em termos culturais, como também prejudicial inclusive em termos textuais. Limito-me a dar apenas um exemplo: desde a metade do século XIX até o começo do século XX, o celebérrimo autor dinamarquês de livros infantis Hans Christian Andersen foi traduzido para o italiano a partir do francês e não é, pois, de estranhar que um dos seus contos mais famosos, A roupa nova do imperador, tenha circulado também na Itália com o título Gli abiti nuovi del granduca (A roupa nova do grão-duque), dado que o tradutor francês, David Soldi, sendo justamente súdito de um império, se eximiu, por razões de oportunidade política, de representar, conforme relata a estória, um imperador nu ( $c f$. Berni, 106-107).

Assim, ao abrigo tranquilizador dessas traduções intermédias, são realmente muitos os casos de não-tradução de línguas "menores" que se registram em cada país ao longo da história, mesmo só daquela mais recente, fazendo de fato sumir dos vários mapas nacionais inteiras literaturas, frequentemente incorporadas à cultura alvo sem 
que haja nenhuma referência à língua original, inclusive na folha de rosto ${ }^{5}$. Nesse sentido, confrontando os dados relativos às traduções literárias publicadas em um determinado país em um determinado período com aqueles inerentes às línguas a partir das quais são efetivamente realizadas, um atlas da não-tradução deveria propor-se a integrar as informações dos tradicionais repertórios bibliográficos, documentando assim não tanto a direcionalidade dominante da tradução ou as línguas de mediação preferidas (que são quase sempre as mesmas: inglês, francês e alemão ou espanhol) quanto sobretudo as línguas apagadas, de forma a podermos raciocinar sobre os motivos e as implicações dessas ausências linguístico-culturais.

Em outras palavras, se o fenômeno da tradução indireta constitui uma das manifestações mais evidentes da marginalidade de uma língua no campo literário mundial, um mapeamento desse traducídio (permitam esse neologismo, alusivo ao "homicídio" da tradução direta que aconteceu e ainda continua de vez em quando acontecendo em muitas culturas) capaz de mostrar onde é que historicamente isso se deu com maior frequência e, sobretudo, quais são, nos vários países, as suas "vítimas" preferidas, talvez possa contribuir não para confirmar de novo o que já sabemos, ou seja, a existência de relações assimétricas de poder entre culturas periféricas e centrais, mas, pelo contrário, também o grau de simetria ou assimetria nas relações de poder entre as próprias culturas perífericas ou semiperiféricas, medindo os tempos e as formas da sua aproximação e desejavelmente inclusive as causas dela.

Não, portanto, uma reflexão meramente especulativa, como se, por exemplo, eu fosse em busca das razões plausíveis que pudes-

\footnotetext{
${ }^{5}$ Dos muitos exemplos possíveis, julgo particularmente elucidativo o do romance da escritora croata Daša Drndić, Trieste, publicado em Portugal pela Sextante Editora em 2019 e traduzido - segundo explicitamente indicado pela folha de rosto - do inglês por António Pescada. Levando em conta que a obra tem como cenário a Itália e que seu título original é alemão (Sonnenschein) torna-se praticamente impossível para o leitor imaginar que a língua em que ela foi escrita é o croata. E é portanto também desse modo que a não-tradução toma corpo à revelia da tradução...
} 
sem explicar a parcial ou total não-tradução de certas obras e de certos autores em determinados países, mas uma análise baseada em dados concretos como são aqueles que distinguem, a meu ver muito oportunamente, entre os autores traduzidos ou não-traduzidos a partir das suas línguas maternas.

Por exemplo, se é um fato - pelo menos cruzando os dados, embora lacunosos, do Index Translationum com coletas bibliográficas ad hoc levadas a cabo por especialistas do tema ( $c f$. Pięta) - que o autor polonês mais traduzido em Portugal entre 1950 e 2000 foi Stanisław Lem, é também um fato que, das doze obras dele publicadas no país naquele período, todas têm como texto de partida não o original e sim outra tradução, a saber, sete do inglês e cinco do francês, o que não apenas levanta uma série de questões a respeito das causas dessas traduções indiretas (falta de tradutores bilingues? Economização de recursos?), como sugere também equacionar os reflexos da assimilação desse escritor - assim como de muitos ou$\operatorname{tros}^{6}$ - na cultura lusitana exatamente pelo viés da não-tradução.

De resto, para além da discutibilidade dos princípios éticos que acabam obstracizando desenvoltamente as línguas periféricas ou supostas tais, há que salientar os efeitos perniciosos dessa praxe em especial no tocante à concreta identidade cultural das obras, a qual, na passagem da língua mediadora para a língua alvo, se res-

${ }^{6}$ E ainda mais interessante, a propósito da literatura polonesa não-traduzida a partir da sua língua materna, é, contudo, sempre em Portugal, o exemplo de $A$ pornografia, um romance de Gombrowicz cuja versão para o português europeu, da autoria de Aníbal Fernandes e publicada em 1988 pela editora Relógio d'Agua, tem como texto fonte a edição francesa, não obstante em 1986 tivesse aparecido no Brasil outra tradução indireta da mesma obra pela editora Nova Fronteira, mais uma vez a partir do francês, mas revista, com base no original polaco, pelo dramaturgo e crítico teatral Yan Michalski: por que então não usar essa não-tradução de Tati de Morais, escrita ao menos em português, ao invés de optar por mais uma nãotradução do francês? Só por razões de maior prestígio cultural da França ou também por desprestígio do Brasil aos olhos de Portugal? Ou não será que estamos diante de um caso emblemático de dupla não-tradução em que, além da língua de partida, o "traducídio" afeta também uma língua intermediária alternativa, tratando-se dessa vez, por sinal, inclusive de uma variante da língua de chegada? 
sente não tanto daquela diluição homeopática do original, quanto sobretudo das específicas convenções e sensibilidades das diversas culturas tradutórias em relação aos aspectos idiossincrásicos, lato sensu, da letra estrangeira ${ }^{7}$.

Como se vê, em suma, as perguntas suscitadas pelo conceito de não-tradução são inúmeras e pode ser que para elas não haja uma única resposta ou que a única resposta possível seja, no fundo, a afirmação de Gideon Toury (26): "translations are, in one way or another, facts of the target system". Mas se as traduções são realmente "eventos" que dizem respeito à cultura alvo, no sentido de que a presença delas repercute diretamente no polissistema receptor, como é então que deveríamos avaliar aquelas traduções cuja precária vida editorial as impede, pelo contrário, de desempenhar qualquer papel na história cultural das suas sociedades, não se limitando apenas a passar das estantes para o encalhe, mas muitas vezes sem sequer chegar às livrarias ou às bibliotecas? Qual a diferença entre essas traduções que não circulam de jeito nenhum ou, no máximo, quase só clandestinamente, sendo o produto às vezes de um sub-mercado editorial que sobrevive às custas de financiamentos alheios ou subvenções, não tendo portanto o menor interesse em divulgar livros já pré-pagos, e a não-tradução propriamente dita, onde - embora mudando a ordem dos fatores (aqui, com efeito, o desconhecimento ou o desinteresse diz respeito aos originais estrangeiros) - o produto final, isto é, a inexistência (virtual ou real) de uma obra, não se altera?

Se, com efeito, um livro existe porque se reatualiza potencialmente a cada nova leitura, o que significa dizer que um livro inexiste sem os leitores que o leem, embora tenha, claro, uma realidade

\footnotetext{
${ }^{7}$ Sobre as repercussões efetivas do notório etnocentrismo das "línguas cultas" ( $c f$. Berman, 46) enquanto pivot languages, ver também P. Couto (441) a propósito do interessante case study da tradução de literatura neerlandesa em Portugal: "Sem termos feito um confronto entre texto de partida e texto-alvo, não podemos ignorar que encontramos traduções indirectas que revelam o desconhecimento da realidade ou cultura dos Países Baixos, por exemplo quando deparamos com nomes de ruas de Amesterdão em inglês ou 'festival' de São Nicolau em vez de 'festa'".
} 
material, não será que é plausível, independentemente de seu valor específico, tratar também essas traduções virtualmente inexistentes à maneira de não-traduções ${ }^{8}$ ? De resto, conforme aparece evidente, o problema não é se essas traduções semi-clandestinas de que se imprimiram poucos exemplares e que não se encontram à venda nem nas bibliotecas tenham leitores efetivos ou não (isso é difícil de se documentar mesmo para as traduções de ampla circulação), mas se possam chegar a tê-los, o que, em tais condições, é pelo menos altamente improvável.

No entanto, o paradoxo de assimilar, culturalmente falando, a não-tradução a traduções reais - embora completamente desconhecidas, além de indisponíveis (ou não mais disponíveis), no polissistema de chegada -, pode ser talvez mais aparente do que real se pensarmos que é justamente essa uma das razões que não raro levam a retraduzir certas obras, ou seja, o fato de algumas traduções terem virado praticamente não-traduções, tendo sumido do mercado editorial de um país ou, de tão desatualizadas que se tornaram linguisticamente, até do horizonte de expectativas dos leitores, precisando portanto ser substituídas.

Eis, então, que a retradução vem preencher essa lacuna, embora evidentemente a gênese de uma nova versão de um texto

${ }^{8}$ Cito dois casos emblemáticos relativos à minha área de competência: Quincas Borba (Viterbo, Edizioni Sette Città, 2009) e Memorie di un sergente delle milizie (Salerno, Arcoiris, 2013) são duas excelentes traduções dos dois clássicos brasileiros de Machado de Assis e de Manuel Antônio de Almeida, que, porém, infelizmente nunca chegaram às livrarias (senão àquelas online) e nem se encontram nas bibliotecas públicas (exceto, como depósito legal, apenas nas Bibliotecas Centrais de Roma e de Florença). A consequência negativa de tudo isso é que, salvo uns poucos leitores tão interessados nessas obras a ponto de encomendá-las diretamente às editoras (mas a tradução de Quincas Borba supramencionada não está mais disponível nem nessa forma), os demais só podem se deparar com elas em algumas bibliotecas, onde, no entanto, as únicas edições italianas de Quincas Borba ou das Memórias ali presentes são velhas versões dos anos Cinquenta (por exemplo, as de Laura Marchiori e de Cesare Rivelli, respectivamente), cujo ranço - nesse caso, refiro-me em particular à de Rivelli - vai em detrimento de uma adequada fruição estética delas. 
fonte preexistente possa ser justificada também por muitas outras razões ${ }^{9}$. Contudo, se é sem dúvida verdade que as retraduções suprem a falta, além das falhas, das velhas traduções, contribuindo por vezes inclusive para aumentar a oferta puramente comercial de versões de uma mesma obra presentes no mercado - o que dá, à primeira vista, a impressão de ser uma coisa positiva -, é porém igualmente verdade que essas retraduções acabam pois dando azo, por paradoxal que pareça, exatamente ao fenômeno da não-tradução, porque tiram espaço a outras traduções possíveis do mesmo autor ou de outros autores da mesma literatura.

Para dar uma ideia de como funcionam sistemas desse tipo, tomo emprestado um case study como sempre genial de Franco Moretti (168-169), o qual no seu Atlas do Romance Europeu, ao falar do mercado desse gênero literário no século XIX, media a difusão das várias obras através da presença delas nos acervos das diversas bibliotecas continentais, concluindo que - cito - "uma biblioteca pequena não escolhe menos itens do espectro morfológico inteiro, ao contrário, reduz a extensão do espectro", ou seja, reduz a diversidade das formas presentes. Traduzindo em outros termos: se o número dos livros e, mais em particular, dos gêneros literários disponíveis em uma biblioteca pequena acaba sendo condicionado pelas dimensões da própria biblioteca, aplicando esse raciocínio ao mercado livreiro o resultado é que o número de textos traduzidos em cada país depende justamente das dimensões desse mercado nacional, que não estando obviamente em condições de traduzir tudo o que vem do exterior, precisa selecionar obras, autores, gêneros destinados a representar aquela determinada literatura.

Por isso, se a fim de minimizar os riscos dos investimentos editoriais, uma cultura tende a se tornar, tal como as bibliotecas periféricas da Europa do século XIX, hipercanônica, continuando a retraduzir os mesmos livros e os mesmos autores, via de regra os maiores, é óbvio que tudo isso vai em detrimento da tradução

${ }_{9}^{9}$ Ver Taivalkoski-Shilov 2015, p. 62: "the causes might be linguistic, aesthetic, cultural, ideological, economic, practical, idiosyncratic, and so forth”.

Cad. Trad., Florianópolis, v. 41, n⿳0 1, p. 15-45, jan-abr, 2021. 
de outros livros e outros autores, inevitavelmente fadados a serem engolidos pelo redemoinho da não-tradução. Tomemos os casos, sob muitos aspectos especulares, do Brasil e da Itália com relação a dois dos seus autores mais canônicos, respectivamente Machado de Assis e Calvino: se, por exemplo, sempre tendo como referência o Index Translationum, dos 529 textos vertidos do italiano para o português brasileiro de 2000 a 2019, dentre as inúmeras traduções de autores religiosos ou de textos absolutamente menores, 62 são traduções de Calvino, isso, a meu ver, longe de ser uma vantagem para o leitor (que quase sempre desconhece os tradutores e, com certeza, não escolhe uma tradução em função das suas expectativas pessoais em torno da "voz" ${ }^{10}$ ali presente, e sim exclusivamente com base no que o mercado editorial disponibiliza para ele), é sobretudo um problema, porque diminui - e sem que frequentemente haja nenhuma necessidade do ponto de vista qualitativo, sendo a maioria dessas traduções contemporâneas umas às outras e todas mais ou menos equivalentes em termos de resultados - a quantidade de obras de outros autores italianos potencialmente traduzíveis no lugar daquelas de Calvino já traduzidas.

Uma situação análoga acontece também na Itália: se, com efeito, dentre os cerca de 200 contos originais de Machado de Assis, as sete coletâneas e as três edições avulsas do Alienista $^{11}$ publicadas em italiano desde 1962 até hoje se têm limitado a propor apenas 38 novos contos (isto é, contos completamente inéditos) do total dos 79 editados, reproduzindo, afinal, quase sempre os mesmos ${ }^{12}$, ou

\footnotetext{
${ }^{10}$ Sobre a noção de "voz" nas traduções ver, em especial, Hermans 1996.

${ }^{11}$ Racconti di Rio de Janeiro, Milão, 1962; L'Alienista, Milão, 1976; L'Alienista, Roma, 1984; Storie senza data, Roma, 1989; La cartomante e altri racconti, Turim, 1990; L'Alienista, Turim, 2002; Galleria postuma e altri racconti, Turim, 2002; Machado de Assis dal "Morro do Livramento" alla Città delle Lettere (con la traduzione di due racconti), Viterbo, 2005; La felicità è un paio di stivali, Ghezzano (Pisa), 2010; Cronache brasiliane, Turim, 2016.

12 Para além de $O$ Alienista, que detém o recorde italiano de quatro traduções (1976, 1984, 1990, 2002, sendo a última, aquela de 2016, apenas uma reedição da versão de 2002), todos os demais contos retraduzidos, 26, têm uma dupla versão. É curioso observar que a única coletânea completamente inédita e cujas
} 
se dos nove romances apenas três (Memórias póstumas, Dom Casmurro, Quincas Borba) estão sendo continuamente reapresentados em novas traduções que pouco ou nada acrescentam às anteriores, sendo, em alguns casos, inclusive piores ( $c f$. Mulinacci), tudo isso infelizmente impede de se empreender a tradução de novos contos ou de novos romances, todos condenados portanto a inexistir também por causa dessa "ansiedade da influência" 13 que evidentemente afeta muitos tradutores.

Assim, se quiséssemos, suponhamos, avaliar o papel da retradução na difusão europeia de Machado, a partir do corpus das suas traduções nas várias línguas do continente, seria importante pormos a ênfase não tanto nos textos já traduzidos, confirmando de fato que toda a Europa - pelo menos o centro do sistema (França, Inglaterra, Alemanha, Itália, Espanha) - traduz mais ou menos os mesmos livros, quanto em particular na comparação entre retraduções e nãotraduções, de forma a entendermos melhor se houver alguma relação diretamente proporcional entre os livros que se retraduzem e aqueles que, justamente por isso, isto é, por "falta de espaço" (Moretti, 189), não podem ser traduzidos, contribuindo, ao mesmo tempo, para a construção de um cânone (inter)nacional do autor, que, porém, nem sempre é autenticamente representativo da produção dele nem coincide necessariamente com aquele do seu país de origem.

Em suma: seja qual for a sua modalidade de significação, quer no sentido de dictum quer, sobretudo, no de actio dicendi, a nãotradução, longe de se configurar como o simples "morfe zero" da tradução, faz na realidade parte integrante dela, se inscrevendo

seis narrativas não têm sido até agora retraduzidas é a mais antiga, Racconti di Rio de Janeiro, ao passo que as duas coletâneas com menor taxa de ineditismo são aquelas publicadas em Turim pela editora Lindau, onde - apesar de a edição de 2016 ser apenas a reedição ampliada da de 2002 - há só um texto novo por edição (Trio in lá minore e Evoluzione, respectivamente).

${ }^{13}$ A respeito do conceito bloomiano de "anxiety of influence" aplicado à retradução, entre antagonismo quase edipiano e um são espírito de competição da parte do segundo tradutor para com o primeiro - mesmo se encontrando, aquele, ao abrigo seja como for confortante da anterior experiência deste -, ver Koskinen, Paloposki 2015.

Cad. Trad., Florianópolis, v. 41, $\mathrm{n}^{0}$ 1, p. 15-45, jan-abr, 2021. 
não só dentro do seu paradigma cultural, ou na superfície da sua manifestação textual, mas também como forma subjacente e, às vezes, inclusive como mecanismo evolutivo da sua morfologia. Vale dizer, no fundo, como outro, possível padrão explicativo da sua história. Da que já foi e da que será...

\section{Referências}

Berman, Antoine. A tradução e a letra ou o albergue do longínquo. Tradução de Andréia Guerini, Marie-Hélène C. Torres e Mauri Furlan. Rio de Janeiro: 7Letras/PGET, 2007.

Berni, Bruno. "Perché ritradurre Andersen? Tener conto del doppio destinatario". Tradurre. Pratiche teorie strumenti. Un'antologia della rivista 2011-2014, Petrillo Gianfranco (Ed.). Bologna: Zanichelli, 2016, pp. 105-111.

Bivona, Kristal R. "Tortured Text: An Analysis of the Absent Pages of Ignácio de Loyola Brandão's Zero”. Mester, XLII [1], 2013, pp. 67-88.

Couto, Patricia. "A tradução da literatura neerlandesa em Portugal". De wereld achter het word/Um mundo para além da palavra. Liber amicorum dr. Luís Crespo Fabião, Augusto Celeste, Van Egmond Jef e Couto Patricia (Eds.). Utreque/Lissabon: Universidade de Lisboa, 2013, pp. 441-464.

Delisle, Jean. L'analyse du discours comme méthode de traduction. Ottawa: Éditions de l'Université d'Ottawa, 1984.

D'Hulst, Lieven. “Translation History”. Handbook of Translation Studies, Gambier Yves and Van Doorslaer Luc (eds.). Amsterdam/Philadelphia: John Benjamins Publishing Company, 2010, pp. 397-405. 
Duarte, João Ferreira. "The Politics of Non-Translation: A Case Study in AngloPortuguese Relations”. TTR, 13 [1], 2000, pp. 95-112.

Felici, Maria Serena. "I tanti volti dell'interdetto. Zero di Ignácio L. Brandão e la sua traduzione italiana". Un incontro lusofono plurale di lingue, letterature, storie, culture, Graziani Michela (ed.). Firenze: Firenze University Press, 2018, pp. 189-200.

Gentzler, Edwin. Translation and Rewriting in the Age of Post-Translation Studies. New York: Routledge, 2017.

Heilbron, Johan; Sapiro, Gisèle. "Outline for a sociology of translation. Current issues and future prospects". Constructing a Sociology of Translation. Wolf Michaela, Fukari Alexandra (Eds.). Amsterdam-Philadelphia: John Benjamins Publishing Company, 2007, pp. 93-107.

Hermans, T. "The Translator's Voice in Translated Narrative". Target, 8 [1], 1996, pp. 23-48.

Koskinen, Kaisa; Paloposki, Outi. "Anxieties of influence. The voice of the first translator in retranslation". Target. 27 [1], (2015): 25-39.

Koster, Cees. "Non-Translation as an Event. The Reception in the Netherlands of John Dos Passos in the 1930s". Event or Incident/Evénement ou Incident. On the Role of Translation in the Dynamics of Cultural Exchange/Du rôle des traductions dans les processus d'échanges culturels, Naaijkens Ton (Ed.). Bern: Peter Lang, 2010, pp. 29-45.

Medvedšek, Mojca. "O panorama das traduções literárias da literatura portuguesa na Eslovénia (1991-2013)”. Língua Portuguesa na Europa Central: Estudos e Perspetivas. Ramos Joaquim Coelho, Grauová Šárka, Jindrová Jaroslava (Eds.). Karolinum Press, Prague, 2016, pp. 94-99.

Moretti, Franco. Atlas do romance europeu 1800-1900. Tradução de Sandra Guardini Vasconcelos. São Paulo: Boitempo, 2003. 
Mulinacci Roberto. "Seis personagens à procura de um tradutor (ou de um critico). Por uma história das traduções de Machado de Assis na Itália como história das não traduções”. O Eixo e a Roda: Revista de Literatura Brasileira. 25 [1], (2016): 109-131.

Osimo, Bruno. "Per un approccio scientifico alla valutazione delle traduzioni". Tradurre. Pratiche teorie strumenti. Un'antologia della rivista 2011-2014, Petrillo Gianfranco (Ed.). Bologna: Zanichelli, 2016, pp. 125-137.

Patai, Daphne. "Machado in English". Machado de Assis. Reflections on a Brazilian Master Writer, Graham Richard (Ed.). Austin: University of Texas Press, 1999, pp. 85-116.

Pięta,Hanna. “Autorespolacosemtraduçãoportuguesa(1855-2010): umlevantamento preliminar”. Cadernos de Tradução, XXVIII [2]. (2011): 97-120. DOI: https:// doi.org/10.5007/2175-7968.2011v2n28p97. Disponível em: https://periodicos. ufsc.br/index.php/traducao/article/view/2175-7968.2011v2n28p97/20372. Acesso em: 03/02/2020.

Pym, Anthony. "Shortcomings in the Historiography of Translation". Babel, 38 [4], (1992): 221-235.

Queirós, Luís Miguel. "Paulo Coelho e Saramago são os mais traduzidos”. $O$ Público. Disponível em: https:/www.publico.pt/2016/11/15/culturaipsilon/ noticia/paulo-coelho-e-saramago-sao-os-mais-traduzidos-1751172. Acesso em: 30.11.2019, 2016.

Seruya, Teresa. "Translation in Portugal during the Estado Novo Regime". Translation under Fascism. Rundle Christopher, Sturge Kate (Eds.). Palgrave: Macmillan, 2010, pp. 117-144.

Seruya, Teresa. "Contributos para uma história da tradução em Portugal". Übersetzen tut not - traduzir é preciso. Contribuições para a teoria e prática da tradução nos mundos lusófono e germanófono. Reichmann Tinka, Sträter Thomas (Eds.). Berlin: Edition Tranvía, 2013, pp. 13-31.

Taivalkoski-Shilov, Kriistina. "Friday in Finnish. A character's and (re) translators' voices in six finnish retranslations of Daniel Defoe's Robinson Crusoe". Target, 27 [1], 2015, pp. 58-74. 
Torres Marie-Hélène C. "Tradução da cultura: literatura brasileira traduzida em francês". Literatura Traduzida \& Literatura Nacional. Guerini, Andréia; Torres, Marie-Hélène C.; Costa. Walter. (Orgs.) Rio de Janeiro : 7Letras, 2008, pp. 31-38.

Toury, Gideon. “A Rationale for Descriptive Translation Studies”. Dispositio. 7 [19-20], (1982): 23-39.

Recebido em: 06/09/2020

Aceito em: 17/11/2020

Publicado em janeiro de 2021

Roberto Mulinacci. E-mail: roberto.mulinacci@unibo.it. ORCID: https://orcid. org/0000-0002-9440-9207. 